\title{
Klong yao and the Performance of Minority Identity in the Siamese Community of Perlis, Malaysia
}

\author{
Chayuti Tassanawongwara ${ }^{1 *} \&$ Hanafi Hussin ${ }^{2 * *}$ \\ ${ }^{1.2}$ Department of Southeast Asian Studies \\ Faculty of Arts and Social Sciences \& \\ ${ }^{2}$ Institute of Ocean and Earth Sciences (IOES) \\ University of Malaya \\ *main author, ${ }^{* *}$ corresponding author \\ e-mail: thought_badman@hotmail.com,hanafih@um.edu.my \\ DOI: https://doi.org/10.37134/mjm.vol8.1.2019
}

Published online: 01 April 2019

Cite this article (APA): Tassanawongwara, C., \& Hussin, H. (2019). Klong yao and the Performance of Minority Identity in the Siamese Community of Perlis, Malaysia. Malaysian Journal of Music, 8, 1-18. https://doi.org/10.37134/mjm.vol8.1.2019

\begin{abstract}
The klong yao performance in the Siamese communities of Perlis was adopted from the Thai community in Central Thailand. Before this adoption, the ethnic consciousness of the Siamese communities was oriented towards a local variation of Thai-ness with similarities to southern Thai people in terms of linguistic and geopolitical references. After the klong yao was actively included in their cultural practices, the Siamese communities began to develop a representative identity that reinforced Central Thai cultural expressions. In this respect, the performance of klong yao reconstructs the identity of the Siamese communities in Perlis, Malaysia toward a Central Thai identity. The shift from a local and marginalised type of Siamese identity to a hegemonic and centralised Thai identity is observed with the choice to use klong yao as a representation of their identity during Malaysia's various occasions for showcasing cultural performances.
\end{abstract}

Keywords: identity, klong yao, performativity, representation, Siamese

\section{Introduction}

This article argues that the Siamese in Perlis, Malaysia selectively construct and represent their identity through the Central Thai klong yao performance genre. The cultural performance of klong yao in their communities constitutes an identity 
construction of 'Thai-ness' through their collective experience of performing, modifying and reconstructing klong yao. The Siamese community's ethnic consciousness of being 'Thai' is the product of shared experience and memory while engaging in this process. Identity construction is a dialogical work-in-progress that hinges on the emergence of the self-conscious cultural performance of klong yao. This view is different from saying that the existence of ethnic consciousness precedes cultural performance. Klong yao culture is seen as influential in reshaping the identity of Siamese communities in Malaysia. In other words, it is through the klong yao performance that Siamese people in Malaysia identify themselves as distinct from other ethnic communities, as well as the way in which other communities have identified Siamese people. In order to support the argument, the authors discuss the historical background of the klong yao in the Siamese communities and its changing reference to central Thai culture. Siamese interactions with other ethnic communities in Malaysia are also discussed to point out that their counterparts acknowledge that klong yao is a representation of Thai-ness.

\section{Historical Background of Klong Yao and Thais}

Klong yao is a Thai percussion instrument and the name derives from its length'klong' meaning 'drum' and 'yao' meaning 'long'. Moreover, klong yao refers to an ensemble consisting of various kinds of percussion where klong yao is a core rhythmic musical instrument in the ensemble and accompanies a traditional Thai dance. The typical shape of klong yao is generally found in mainland Southeast Asia namely Burma, Lao, Cambodia and Thailand. Since the Ayutthaya era (circa. 1351 to 1767), klong yao was likely a part of Siamese war heritage when the Burmese tried to colonise Ayutthaya. Aural narratives about the Burmese and klong yao are found in Thai traditional songs called phama toong-le. The lyrics were written by an anonymous person to describe a celebration of an old Burmese man with proficient skills in playing klong yao and who immigrated to Thailand.

There are many kinds of long drums in northern and northeastern Thailand including the Isan long drum. Although the Isan long drum is different from the klong yao of central Thailand in terms of both shape and usage, historically both served central roles in religious rites and local belief ceremonies. The Isan long drum tradition has faced social and economic challenges. However, the musical tradition of the Isan long drum survived through adaptations of its appearance and inclusion with modern musical instruments. The Isan people have attempted to sustain their long drum practice by integrating their musical tradition into the music programmes of local schools (Chuthawichit, 2014). Northern Thai music status as folk music in modern educational institutions plays a role in shaping cultural identity (Pitupumnak, 2018).

According to Field Marshal Plaek Phibulsongkhram (1938-1944 and 19481957), the Rathniyom or Thai cultural mandate revealed that the klong yao had already existed during the Ayutthaya period into the current Rattanakosin era. During Field Marshal Plaek's administrative term as Prime Minister, the country was run by mandates that aimed to create a uniform practise towards civilised Thai culture. Traditional Thai cultures were separated into categories of 'civil' and 
'uncivil' practices. A campaign to foster a 'true Thai culture' was the agenda of Pibul's cultural revolution (Numnonda, 1978). The revolution attempted to make people seriously concerned about colonisation and the country's independence. One way to maintain independence was to trust Prime Minister Marshal P. Phibulsongkram and his mandates. After the mandates were promulgated, there were attempts to cultivate the Siamese as modern Thais as well as to establish local and folk cultures as national customs. The results of these mandates had an effect on the performing arts as well. There were creations to standardise klong yao performance along with fixed choreographies. Previously klong yao had been considered a folk entertainment since assimilation with the Siamese. Perhaps as a result of nation-making, the new civilisation might be identified as a new concept of national identity that was centralised by Thai policy. Klong yao performance therefore contributed to this nationalising role. Notably, music and dance were developed under the Rathniyom mandate based on the idea of a central Thai model which spread from Bangkok to other Thai regions.

In 'A History of South-East Asia', the Chinese were referred to as 'Sien' during the Sukhothai kingdom, while the Khmer used the word 'Siam' which means 'barbarian' from the area of the Mekong basin or Chaopraya River. Although Thais had been in existence as a people for thousands of years before the Christian era, the first Thai kingdom that was established in what is now Thailand was Sukhothai in 1238. The coming of Thais contributed to the decline of the Sri Vijayan Empire. A Sukhothai king, Rama Khamheng, struck the decisive blow to surrounding rivals in 1292 and expanded his power to the south from the Menam Valley in Thailand into the Sri Vijayan ports in the southern part of the Malay Peninsula (Hall, 1970).

A consistent perception of Thais in Thailand and Siamese in northern Malaysia is that both were once part of the Kingdom of Siam. However, the four Malaysian states of Kelantan, Terengganu, Kedah and Perlis used to be a part of the Sukhothai realm for centuries until the reign of King Rama V. More recently these areas were given to the British when Malaysia was colonised. The Thais in the four states are similar to Thais in southern Thailand - approximately several thousand Siamese households with similar traditions, temples as well as Thai architecture (Aryuwatthana, 1974). Colonial histories on the southern extremities of the AngloSiamese boundary zone do not mention the existence of a Thai Buddhist village nor the constant traffic of people and produce that criss-crossed these political margins (Johnson, 2004). The status of the four northern Malaysian states that were part of Thailand was such that they were not totally controlled under the Siam ruler. For example, the Raja of Kedah had to struggle against Malay neighbouring states and rivals in the region to maintain the power of the ruler (Winichakul, 1994).

A challenging issue arose as to how Siamese are supposed to identify themselves as either Thai or Malay since a variable and complex relationship exists between ethnicity and culture. Ethnicity is the enduring and systematic communication of cultural differences between groups considering themselves to be distinct. It appears that wherever cultural differences are made relevant through social interactions, it should be studied at the level of social life and not at the level of symbolic culture (Eriksen, 2010). Moreover, ethnicity is relational and also situational. The identity of 'Siamese' is self-constructed and occupies different roles 
in a given social structure. Identity is based on expressing behaviours, such as Siamese identity expressed through musical dimensions (Burke \& Stets, 2009). Tools of performance such as actions, features and sound-making construct identity.

The underlying idea of performativity as applied in the context of performance studies is that one's ethnic identity is constructed through one's repetitive performance of the ethnicity. Schechner (2013) suggests one way of understanding a performance is that it applies to all kinds of displays, e.g., the performing arts, sports, rituals, play and the performances of everyday life. Schechner states that performance must undergo a time-space sequence, which includes three phases of proto-performance, performance and the aftermath. In light of these conceptions, this study aims to examine the reconstruction of the klong yao musical performance through the assumption that the Siamese in Perlis construct, reconstruct and maintain their Thai identity amidst the multi-cultural ambiance of Malaysia through klong yao. This study attempts to explain why the klong yao should be considered performative, through actions that construct people's Thainess in a way that is similar to Thai-ness expressed by Thai people in Thailand. With this notion in mind, the researchers analyse the klong yao performed by the Siamese community in Perlis and describe how each part of the musical performance is performative whereby members of the Siamese community identify themselves as belonging to Thai culture and are also distinct from other ethnic groups in their locality.

Stories told by Siamese elders reveal that the klong yao was introduced to Siamese communities in Perlis approximately fifty years ago. A fifty-year-old Siamese abbot, Chia a/l Choi related the first account from his memory that he had never seen a klong yao during his childhood. The musical genres for entertainment purposes witnessed at that time were the nang talung (shadow puppet) and norah (the Southern Thai Dance). Informant Loong Ruern (Alon a/l E Keliang) added that the first klong yao ensemble was offered at the Suwankhiiri temple when he was still a child. His father Pu Kriang, who coordinated the 'Tod Krathin' events, invited the then governor of Satun province (Mr. Supayok Panitchawit) to offer a krathin donation to the temple. Pu Kriang, along with other Siamese villagers, went to Kuala Perlis to receive the governor and his entourage. They offered the klong yao ensemble in the Tod Krathin procession. After the festival ended, the instruments from the ensemble were given to the Suwankhiri temple for public use. It was the first klong yao ensemble in Guar Musang village. Loong Ruern added that it was his father who took care of the first klong yao ensemble and that his older brother and friends became klong yao musicians in the early days. During the early development of the klong yao the musicians imitated the sounds that they had listened to played by others without being trained by professionals. But when it was felt that this was not adequate, his father invited a music teacher from Thailand to train them, consequently forming the first klong yao ensemble for the Suwankhiri temple.

Informant Pi Pramoot narrated the second account of klong yao coming to the Siamese villages (Pramoot a/l Puan) and Por Tan Chiang (Ven. Chia a/1 Choi). There was a monk named Por Tan Klom who travelled from Thailand to Macchimaprasit temple to teach the Thai language among the Siamese communities. Along with the language, he imparted other Thai cultural expressions such as Thai 
folktales (nithan), Central Thai chanting (suad montra), Buddhist chant (tripitaka), etc. The klong yao was selected to be taught to the children as it was the easiest musical instrument to play. The drums were brought into the community from Thailand several times. Loong Nam (Boonnam a/1 Endin Pelian) said the formation of the klong yao ensemble was a success as he had not been interested in practising the klong yao. However, he is now active in the Macchimaprasit temple klong yao ensemble and is encouraging the young people to preserve this musical performance. Therefore, Por Tan Klom is known as the pioneer of the klong yao tradition in Jejawi as well as the first klong yao master in that Siamese community.

Another account was shared about Guar Nangka village in Juping. Another informant named Loong Kruern (Ken a/1 Tin) mentioned that in his youth, other Siamese villages had many klong yao while Guar Nangka village had none. He and his like-minded friends went to Sangka Rattanaram temple (Wat Takoi) in Thailand's Songkhla to find a music master who was able to teach them how to perform klong yao for use in religious events. They learned the rhythmic patterns of the klong yao and its related traditions under the master's training. Before returning to their village, they bought a set of klong yao for use at Kampung Guar Nangka temple in their home community. Until today, Loong Kruern has managed to allocate his free time to teach the klong yao to children including his young adult son, Samart.

These narratives shed light on the fact that klong yao was not the original practice of the Siamese communities in Malaysia. In order to create a more expressive Thai musical tradition, the Siamese community borrowed the klong yao tradition from Central Thailand and incorporated the klong yao into their traditional religious rituals and transmitted klong yao knowledge to the younger generations. In this regard, it was revealed that the early version of the klong yao performance in the Siamese communities resembled the southern Thai tradition in its simplified totality.

Klong yao knowledge was transmitted as an oral tradition to the children using an approach that was simple and easy to learn. The teachers used the onomatopoeia technique-verbalising the formation of rhythmic patterns by imitating the sound of instruments to teach the drumming patterns. Loong Chun imitated the drum sound as 'pab' for a strong sound and 'pleum' for a weak sound. The two sounds represent the basic rhythmic pattern. In addition, an interlocking sound, 'teung', is produced by using a finger to hit the drum edge.

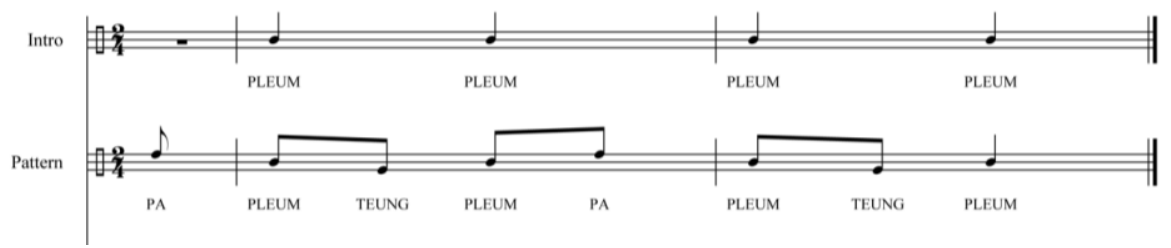

Figure 1. Loong Chun's klong yao style 
The pattern frequently heard in the music performed by the Chaiya Ensemble is the sound produced by means of imitating the 'tab' pattern, i.e., the two main sounds - the strong beat, 'jab' and the weak beat, 'tum'. Examples of four different patterns created by the Chaiya Ensemble show the influence of the 'tab' patterns.

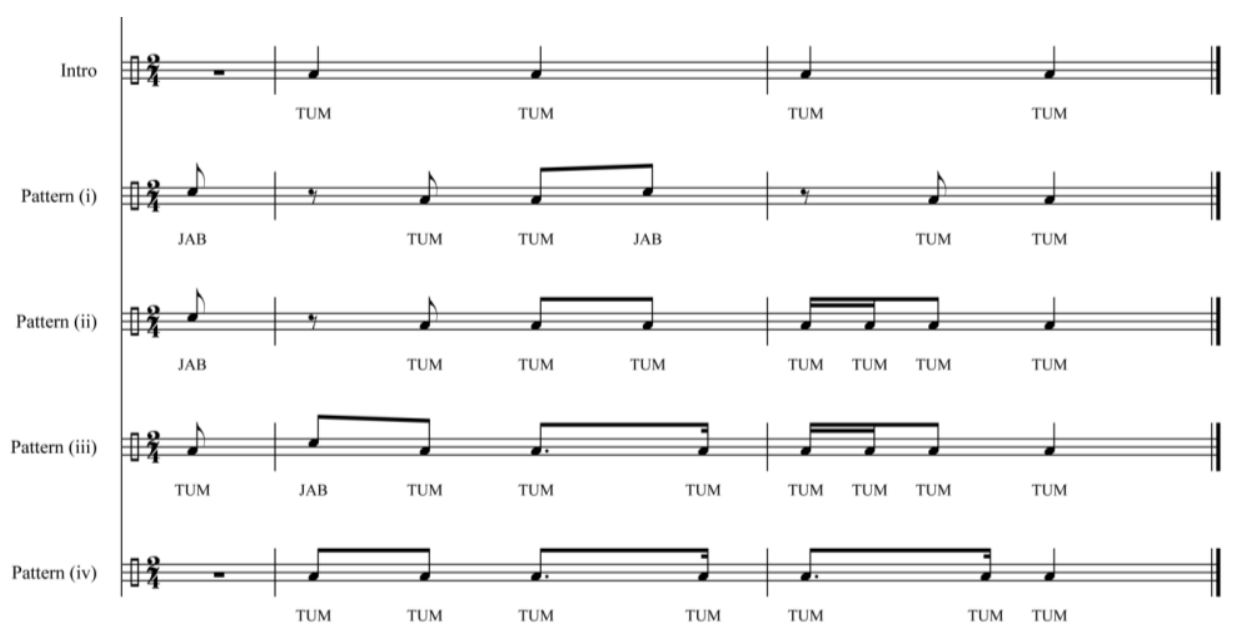

Figure 2. Chaiya's klong yao patterns derived from the Tab pattern

Loong Chun is among the first generation of musicians who witnessed the initial phase of learning the klong yao after musical instruments were brought from Satun to the Suwankhiri temple. Chun mentioned that those musical forms and rhythmic patterns were not complicated. The sounds made came in variations between strong and weak beats. This simplified method of playing the klong yao made learning possible for children. He emphasised that the klong yao must be preserved by transmitting its knowledge to the children. In training, he lets the children play Mhong while watching each student play the main rhythmic downbeat. He then continues using the klong yao pattern. This method facilitated the successful learning of klong yao for non-professionals. Therefore, klong yao had the advantage of being easy to learn through imitation. Musicians perform with the klong yao on various occasions especially at religious festivals of the Siamese communities. Moreover, the performance is also included in some social functions as cultural expressions specific to the Siamese communities.

\section{Functions of Klong Yao in the Siamese Communities}

At the beginning, the klong yao performances were played during religious occasions. However today, the Siamese have expanded its function into many other special occasions as well as being part of events in other ethnic communities. The fact that the Siamese played klong yao as a prelude to ceremonies provides it with possibilities to be performed at the beginning of virtually any event. The welcome 
prelude might be a part of a mixed ceremony involving Siamese, Chinese and/or Malay participants and attendees. This was how the klong yao was presented to other ethnic communities as a Siamese performance that best reflected the performers' Thai identity. Thus, this study emphasises again that members of Malaysia's Siamese community chose the klong yao ensemble that was adapted from the Central Thai musical tradition to represent their identity. The same choice of ensemble was also observed in two festivals - Citrawarna festival and the Merdeka festival. During Citrawarna, the Siamese community used the klong yao to represent their culture as musically distinct from other Malaysian performances and could also easily be merged with the marching parade. The Kedah state celebration of Malaysia's independence on Merdeka Day included a klong yao performance to represent the Siamese community and to 'perform' national unity. The use of the musically distinct klong yao ensemble highlighted its place within the nation of its presence as a unique Siamese community in Malaysia.

In religious settings, klong yao is part of various religious-cultural events within the Siamese communities. Although klong yao music seems to negate the spirit of monkhood, i.e., a state of purity by refraining from entertainment and indulgence in worldly pleasures, klong yao serves many important functions in Buddhist temples. First, the performative culture of klong yao is closely tied to sacred realms when instrumental music is offered in temples as a religious treasure. The klong yao is perceived as 'necessary' property for every Siamese community temple. The offering of klong yao music is part of the merit-making rituals. Second, it was used to encourage people to go to temples on important cultural events. For example, despite its roots in Thai culture rather than Buddhist, the Loy Krathong festival usually took place in the vicinity of the temples. The klong yao performance is the hallmark of the event as it is given a distinct role in leading the opening procession and expected to bring the villagers closer to the religion and make them feel attached to the temples.

The most important role of the klong yao in ritual space is its facilitation of religious ceremonies. The Siamese like to perform the klong yao in every religious event except funerals. I will relate my experience in the Tod Krathin festival at the Kubang Tiga temple in October 2017 as an example. Tod Kathin or Robe Offering Month to the monks which falls at the end of the Buddhist Lent or called as 'Rains Retreat' usually takes place for three lunar month cycle (July-October) where the farmers are planting their crops. Buddhists show their appreciation to the temples by presenting food, money, useful household items and cleaning supplies. The festival took two days, i.e., Tod Krathin eve and Tod Krathin day. While Nang Talung, the Southern Thai Puppet performance was hired from Thailand to celebrate the event on the eve, the klong yao was performed on the actual day of Tod Krathin. In the morning, the event emcee encouraged the participants to go to the temple. Those interested in joining the klong yao dancing were told to gather at a former abbot's shrine and take part as the procession proceeded. After lunchtime, the klong yao musicians began by paying salutation to sacred beings to ask permission for performing at the temple. After that, the klong yao performers led the participants to circum-ambulate the temple by walking clockwise three times. This made it obvious that the klong yao music was performed 
as an essential part of the religious ceremony that took place in the Buddhist temples.

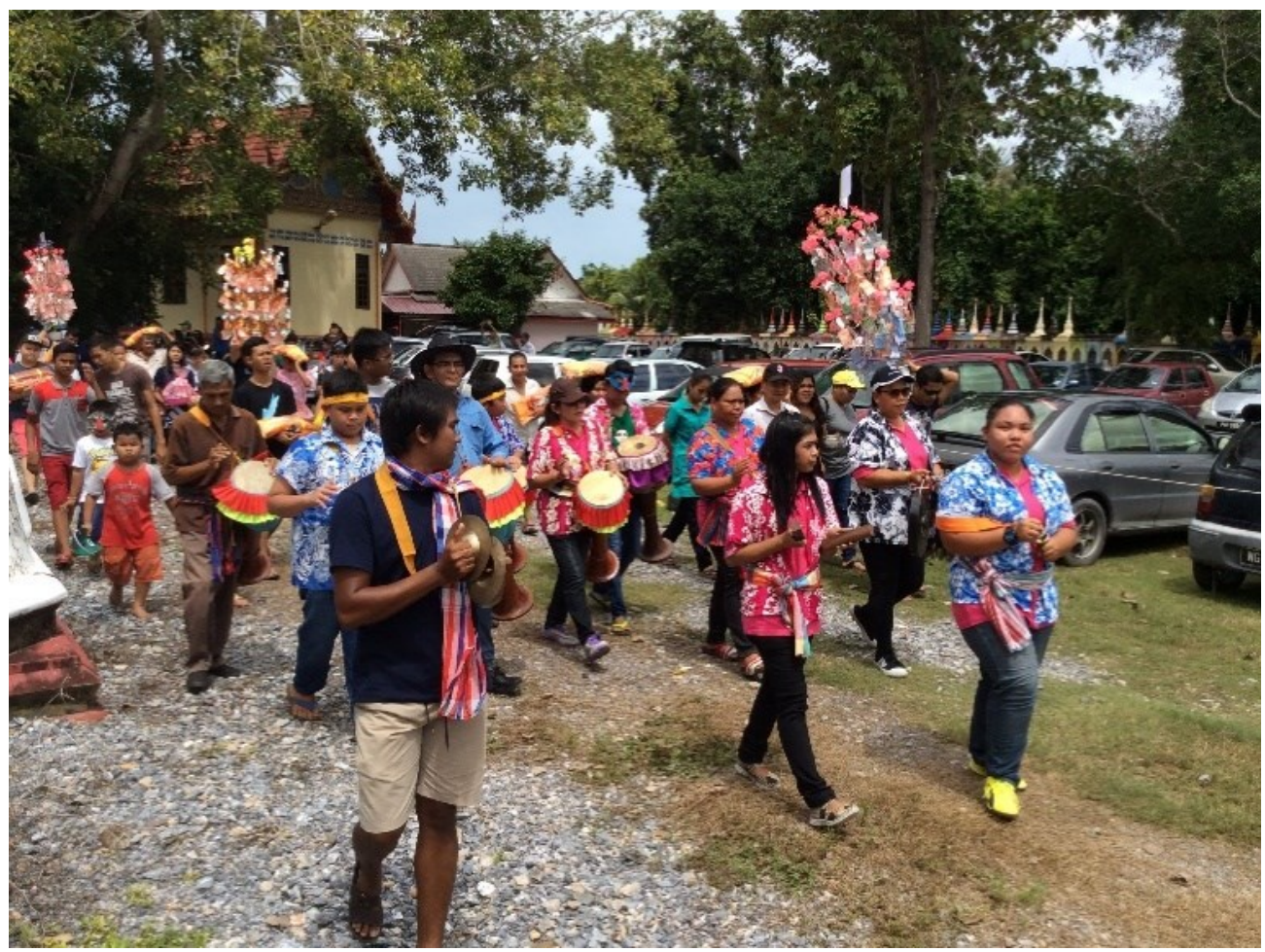

Figure 3. Klong yao in Tod Krathin ceremony, Macchimaprasit Temple 2016

Therefore, when Thai-ness was expressed through the religious practice of a klong yao performance, klong yao reinforced a sense of belonging and consolidated an ethnic consciousness of the Siamese minority community. The cultural practice rendered their religious interconnection with ethnic consciousness. Solidarity of the Siamese communities was reinforced through learning and practicing the klong yao while Thai-ness was defined within the realm of Buddhism. A sense of belonging was attached to the inclusion of the klong yao performance into various ceremonies that had the effect of forming the participants' Thai identity and representing Siamese culture in the ethnically diverse context of Malaysia.

\section{The Klong Yao Traditions and References to Central Thailand}

The Siamese speak southern Thai dialect as their mother tongue and speak Malay for daily communication. A number of Siamese prefer to communicate with ethnic Chinese people in either Hokkien or Mandarin. However, the central Thai dialect was taught by Siamese parents to their children in the temple-based schooling. Television was also crucial in cultivating the language skills of the Siamese as they 
invariably watched Thai TV programs and soap opera series. In religious settings, Buddhist monks were instructed to chant with Thai translations of Pali texts. The Siamese had internalised the language system of the central Thai dialect through religious practice. Thus, the central Thai language is integral to their religiouscultural life. With the increasing influence of Thai culture in the lives of Siamese, the southern Thai dialect began to fade. The point of reference that these Siamese communities made when talking about their Thai culture had shifted from a southern Thai variation to that of central Thailand.

In the next section, the klong yao performances are analysed to locate its performativity in shaping the Thai identity of Siamese to be more of the central Thai culture than the southern Thai cultural traits. The performance elements that will be addressed below are songs and vocal components, bodily gestures and physical movements involved in dancing, as well as costumes and dressing styles and the klong yao procession and order of performance. Moreover, the attempts by Siamese communities to enhance the performance based on the central Thai standards are also counted as an indication of the shift in their cultural reference.

\section{Songs and Vocal Components}

The central Thai dialect occupies the space of cultural performance. Klong yao performances included numerous kinds of songs, i.e., 'Pleng Klong Yao' - also known as 'Pleng Rum Vong' - 'Pleng Look Toong', and melodic conversation and undulating shouting. The central Thai dialect is used throughout the singing of 'Pleng Klong Yao' and 'Pleng Look Toong'. 'Pleng Klong Yao' includes a variety of songs composed specifically for klong yao performance while 'Pleng Look Toong' emerged after World War II and was known as Thai country music. Klong yao songs are simple in their rhythmic patterns, following cyclic repetitions that are commonly adaptable to variations making it easy for singers to apply lyrics to very basic patterns.

'Pleng Rum Vong' often involves folk stories mainly describing the lives of people in the countryside or the imagination of local Thai customs. 'Pleng Rum Vong' involves group dancing where male and female dancers dance in pairs to form a circle. The most famous song for a klong yao performance is called 'Loy Krathong'. This song is also very famous for Siamese and Thai speaking populations elsewhere. The Siamese tend to sing the song frequently during parading. The original function of 'Loy Krathong' was for the Loy Krathong festival in November. The festival's purpose by origin is to pay homage to the goddess of rivers whereby participants float an oblation basket. The song is sung to mark the festival but at the present, the song is used in almost every event with the klong yao. The Siamese perform the klong yao in the 'Loy Krathong' festival and other religious ceremonies and is thus characterised as representing Thai culture. The lyrics of the song are as follows: 
Sanook Kanjing Wan Loy Krathong. 'Enjoyably on Loy Krathong night.'

Loy Loy Krathong 'Floating oblation baskets'

Loy Loy Krathong 'Floating oblation baskets'

Loy Krathong Kanleaw. 'We have done floating.'

Kor Chern Nong Keaw Okma Rum Vong... 'Please come and join Rum Vong'

Rum Vong Wan Loy Krathong.

Rumwong Wan Loy Krathong. 'Rum Vong is for Loy Krathong day.'

Boon Ja Soang Hai Rau Sookjai. 'Rum Vong is for Loy Krathong day.' Boon Ja Soang Hai Rau Sookjai. 'Benevolent would make us happy.' 'Benevolent would make us happy.'

These lyrics could be adapted to fit klong yao rhythmic patterns. Each poetic phrase was adjusted in a round of four-beat patterns. 'Pleng Rum Vong' and klong yao were perfect in matching and expressing a sense of Thai traditions. The Siamese benefitted from the powerful music as the 'Loy Krathong' song recalled traditional behaviour. Some dialect lyrics were spoken and emphasised to reinforce the sounding identity.

'Pleng Look Toong' exemplified contemporary modern Thai songs in the $20^{\text {th }}$ century before the aftermath of World War II. Its popularity was influenced by Western harmonies mixed with Thai singing style. Siamese teenagers in klong yao teams still favoured these classic songs that were popular among people in the 1970s. 'Pleng Look Toong' was also written based on Thai poems similar to 'Pleng Rum Vong' songs. The poetic lyrics of 'Look Toong' reflect a rural lifestyle, poverty and cultural traits as well as the changing social conditions of central Thailand. The passion of the songs brings back a nostalgic milieu representing a variety of what life used to be like. Additionally, the lyrics remind the Siamese community of a shared history with Thai people. A sense of belonging is created as the songs encourage them to imagine a land where their ancestral lines converged. Certainly, this has the effect of strengthening a sense of Thai-ness among member of the Siamese community.

The vocal process has one more way of expressing sound such as the use of an important gimmick in klong yao parading. At the start of the parade procession, one of the musicians or participants begins by shouting an undulating sound, and the other reacts with a booing sound - called 'Ho Sam La'. 'Ho Sam La' typically launches parades. The tradition of the undulating shouting is to announce that the ceremony or event is about to commence. It is intended to signal to the participants to get ready and is used to gather people in an event. Thus, 'Ho Sam La' is a verbal symbol of the klong yao performance. The shouting is probably interpreted as expressing common actions and the response to the shouting in the musical performance is limited to those who are from the same fundamental tradition. Undulating shouting also appears in traditional Thai dramas or court musical ceremonies from Central Thailand. Below is an example of the sounds made during the shouting.

$$
\begin{aligned}
& \text { Asking: Ho ... hee ... ho ... hee ... ho ... hee ... ho ... hee ...hoy } \\
& \text { Replying: Heew w w w }
\end{aligned}
$$


Lyrics and songs are sounding tools to fulfil a qualitative sound content that is akin to Thai in order to construct identity. Presenting Thai language, especially the central Thai dialect is evident and appears in most of the processes related to performance such as training how to speak and sing, how to act by singing, shouting and expressing words as Thai. Thus, representing identity is performed by identifying as a person who speaks Thai. In the use of Thai language, whether meaningful or meaningless, both are functional. Through performing, sound and language encourage participants to belong to what they are performing. Siamese is characterised as a legal minority and it is easy to claim that the majority still interacts with Thais like siblings. Speaking the southern Thai dialect in daily life is perhaps too common to effectively make them distinct from others surrounding them. Regarding similarity, groups of Thai Muslims in southern Thailand can speak the southern Thai dialect and Bahasa Melayu.

When people speak, the language could represent religion. For example, the Siamese speak Thai as an image of Buddhism and the Muslims speak Bahasa Melayu as a character of Islam (Ryoko, 2005). The language and vocal sounds in the songs and lyrics influence Siamese behaviour, thoughts and feelings through which they claim Thai character. The performance of klong yao ties Siamese people to each other strengthening their shared identity expressed through how they sing, shout, organise and create compositions for klong yao. Performance helps Siamese participants to shape the selected language and dialect that is used during performance. However, speaking the language in daily life is different from how it is used in the klong yao performance. For special occasions, performances are opportunities for the dialect of Siamese to be used in performing time by those who want to perform as central Thai people and who also want to be understood that they can be 'real' Thai people through language. To build a clear image of being Siamese, the klong yao performers use the central Thai dialect during the klong yao performance.

This means that the central Thai dialect is implicitly identified as the performing language for this particular performance of Siamese. Although the central Thai dialect is blended with Siamese, the performers clearly know where the language came from and how to display it to construct identity. Therefore, it could be said that the vocal elements of the klong yao performance are performative in constructing Thai identity through special reference to the central Thai culture. Furthermore, the bodily gestures and patterns of movement during the performance are also effective in making central Thailand a point of reference for those who participate in cultural practices.

\section{The Klong Yao in Siamese Relations with Other Ethnic Communities}

This section will take into consideration the roles of klong yao in boosting ethnic relations between Siamese communities and other ethnic groups in Malaysia. The recognition of klong yao as a unique feature of Thai culture by Malay and Chinese communities indicates that the formation of local Siamese identity has been affirmed. To the Chinese, klong yao is primarily accepted as part of secular events only allowed to be performed in the non-religious parts of the ceremony. For the 
Malays, klong yao must not involve religious elements. Thus, Chinese and Malay communities identify klong yao as representing the Thai community in cultural terms.

In Perlis, the Raja's birthday is a celebration for people to participate in paying homage to the Raja. During the research, it was observed that on the stage, a dozen musicians and dancers performed and sang Thai songs in the central Thai look toong style. Therefore, the Malay Raja's birthday is an event where Siamese can openly express their music to the public. Siamese usually include klong yao as their ethnic music to display the presence of Siamese ethnic character. This character is of course distinguishable from the Chinese who created the Lion dance, and distinct from the music and dances of Indian groups. It is likely klong yao helps Siamese to represent themselves through culture and gain credibility in highlighting Thai-ness.

Malays also acknowledge klong yao as representing Thai culture of the Siamese communities by allowing a performance during the celebration of Merdeka Day. Every year on 31 August, officially proclaimed as Merdeka Day, all Malaysians celebrate Malaysia's independence from the colonial British, (see Figure 4 below). The Siamese have long been known as people residing at the northernmost area of the Malaysian peninsular. They are also members of the Malaysian nation and treated as bumiputera according to the applicable law. The Siamese have never denied they are Siamese Malaysians in the midst of the development of a Malaysian image and presenting a Siamese identity. They use the klong yao to promote Thai performances of tradition and culture. The dance movements harmonised with the rhythm of the klong yao distinguish them from other ethnic groups. Merdeka Day lets the performers to openly exhibit Siamese cultural heritage.

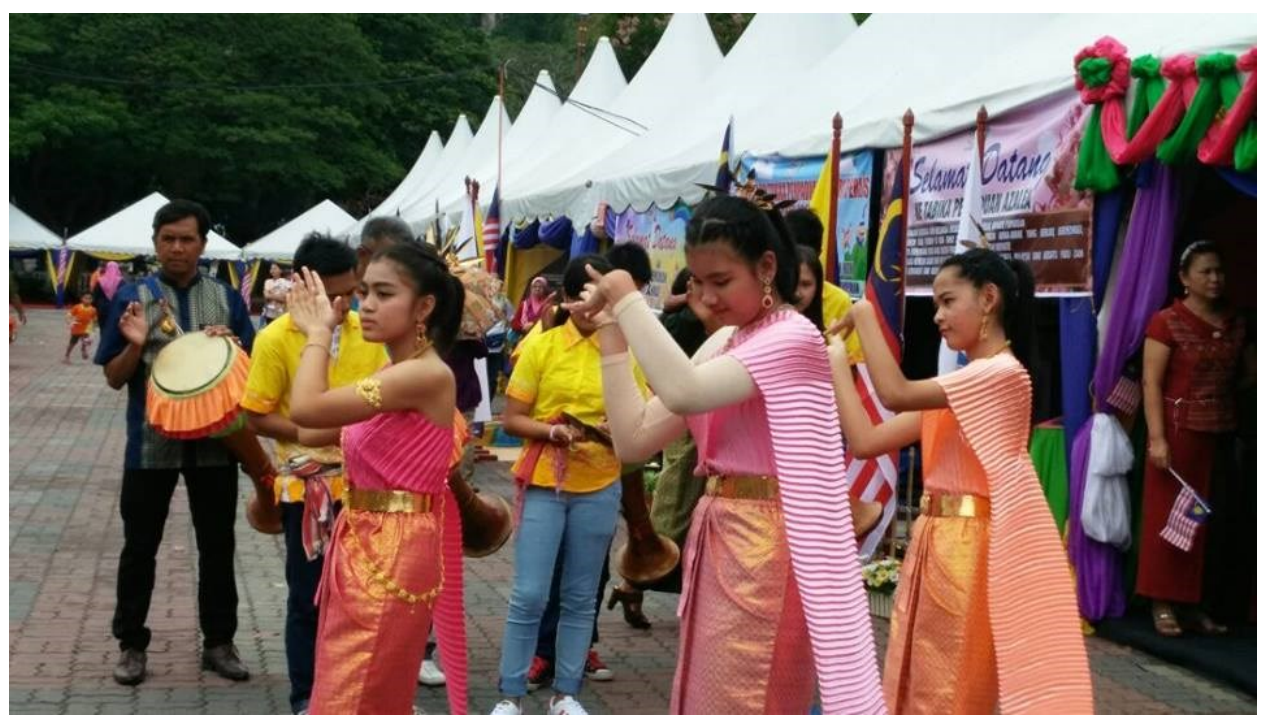

Figure 4. Dancing and playing the klong yao at Merdeka Day 2016 
The use of the klong yao crosses and intersects with other ethnic groups, specifically the Chinese and Malay communities. The Siamese relationship with the other ethnic groups is that of being bearers of a minority tradition. Their performances display not only music and dance but also implicitly symbolises reciprocal relationships that show how the Siamese behave with other people and how other people treat the Siamese.

Loong Chun said that his klong yao ensemble was usually invited by the Chinese to be a part of the vegetarian festival procession on the first day of Merdeka. He added that his Chinese friends always ask him to prepare the klong yao a week before the celebration. He said that the ensemble and musicians must consider the celebration as sacred and that the people attending are very faithful to their deities. Hence, the klong yao has to be played in a dignified manner that is respectful of the ceremony. When the Chinese festival comes, it is common for the Siamese to help the festival irrespective of whether or not the Siamese performers have been requested. In addition to the vegetarian festival, the Chinese communities also welcome the klong yao performance during celebrations at holy shrines and as part of ceremonies paying homage to deities. The Chinese mostly follow Mahayana Buddhism as one of the two main Buddhist branches. The sect contains different beliefs and understandings according to the teachings and practice of each sect. Mahayana has traditions that refer to Bodhisattva and the deities. A belief in the existence of a deity is prevalent among both the Chinese and the Siamese who live around Perlis.

\section{The Bodily Gestures and Patterns of Movement in Klong Yao Dancing}

Siamese dances are categorised into norah which is based on the southern Thai dance norah and rum, a central Thai dance. The Siamese community of Perlis prefer the central Thai dance, rum, which has an allegro (fast) beat. The bodily movements and gestures that accompany the klong yao is known as rum translated as 'dance' in Thai. The dance is rum vong (traditional folk dance). The styles and patterns are different from the dances of the Malays, Indians and Chinese. The Siamese express emotions through dance and each bodily movement and gesture refer to specific meanings.

Dancing to klong yao accompaniment is classified into two types; first, tum terdterng, a traditional Thai dance created by an order issued by the Thai government about eighty years ago under a cultural mandate. Influenced by cultural civilisation, rum vong is a standard dance constructed from folk dance and developed by the National Fine Arts Department to form a national dance. Consequently, Thai dances became more standardised as rum vong became popular. The dances were choreographed to the klong yao instrumental music accompaniment whereby male and female dance in pairs. Rum terdterng is one of the standard dances that was created by developing folk dances according to the ideas of central Thai creators.

Second, in rum, dancing is not limited to standard movements. In Thai tradition, dance movements focus on the hands and the top part of the body. Rum in klong yao is used to express enjoyable emotions through natural movements that are 
not confined to fixed patterns. Common people participate in the dance by moving their arms while klong yao is performed. The movements are similar to rum vong and rum terdterng styles of spontaneous expression through moving hands, arms and bodies. A combination of rum and klong yao presents the identity of the Siamese community in Perlis and the gestures represent the cultural and social background of the Thai community in Malaysia.

Since there are no fixed protocols on how one should dance, the Siamese are able to create personal movements while referencing rhythmic beats. They express self-creation as Siamese, especially women, who enjoying performing rum to accompany the klong yao performance. Today, rum as a dance for the klong yao, takes place at almost every community event and ceremony. Its function, as mentioned previously, is designed to serve the Siamese klong yao tradition.

\section{Costume and Dressing Styles}

Klong yao performance also presents traditional costumes as part of its cultural expression. The styles of dressing adopted for the cultural performance are based on central Thai culture. The klong yao players wear songkran shirts and colourful girdles to be distinct from others. Siamese characters are highlighted while wearing the shirts, to represent that they can follow the current fashion and trends in modern Thailand. The Siamese acquire certain items such as songkran shirts in order to mimic Thai costumes. In the case of southern Thai or northern Malay costuming, local dresses are inadequate for presenting a clear distinction of being Siamese and their connection to Thailand. Wearing a costume is a trend that emerged among the klong yao team. When Siamese teenagers gather, the klong yao team is proudly presented in polo shirts with Thai letters emblazoned on the back of the shirts. The phrase 'local culture lovers' is written in the Thai language.

With regard to self-identification through costuming, the Siamese pursue a style of dressing indicative of Thailand. They cross the border to purchase shirts from Hatyai in southwest Thailand. However, there is another kind of costume that is not linked to the songkran festival. For example the use of polo shirts by the Siamese is an attempt to symbolise neutral meanings through costuming. These are shirts emblazoned with Thai words and the phrase is perceived and observed to be Siamese in the use of characters from the Thai alphabet. The Thai alphabet represents Thai culture through the use of language. Musicians who wear the shirts might agree with the idea of cultural representation through performing identity that plays a central role in the klong yao performance. Traditional Thai dresses from Central Thailand such as shud thai prarajaniyom, the Thai royal dress for women, are worn during religious events and klong yao performances. Costumes, such as songkran shirts, emblazoned shirts or traditional dresses establish a symbolic process that Siamese use to characterise who they are, particularly in klong yao performances. The tendency to utilise Central Thai costumes and fashion as part of klong yao performances asserts the Siamese communities of Perlis and their preference for the construction of their identity. 


\section{The Attempt to Enhance the Performance Based on Central Thai Standards}

The Siamese community of Perlis continuously aspire to improve their performance of klong yao up to Central Thai performance standards. Their attempts include learning by imitating multimedia materials produced in Thailand such as compact discs (CDs) and videos cassettes, and by viewing the YouTube channel. The Siamese in Malaysia also engage Thai professional teachers and klong yao musicians to teach their musicians. In addition, they also organise klong yao contests that are evaluated based on Central Thai performance standards.

The first klong yao competition took place at Jitra temple, Kedah in the early 2000s, approximately twenty years ago (Loong Chun @Chun a/1 Cheng, personal communication, 15 March 2017). Since that time, a klong yao competition is an established event that gathers klong yao ensembles from the four main states in Malaysia with Siamese communities, Perak, Kelantan, Kedah and Perlis. During the competition, Siamese klong yao musicians and Thai music teachers from Thailand are invited to judge the competition. The evaluation criteria include creativity, musicianship skills, musical technique and harmony between the klong yao musicians and dancers.

\section{Conclusion}

In our attempt to argue that klong yao is effective in shaping Thai identity among the Siamese people in Perlis, we took into consideration the historical background of the klong yao performance in their communities. The research established that klong yao has not been a part of Siamese culture in Malaysia until recently. Before the Siamese adopted the klong yao as part of their religious practices and cultural exchanges, their ethnic consciousness was not associated with central Thai origins. Rather, southern Thai cultural traits were manifest in their communities through the language used and the geopolitical reference. After the Siamese communities embraced the klong yao, their ethnic consciousness was gradually re-shaped with a stronger reference to central Thai communities through components of cultural performance. The Siamese in Perlis strengthened Thai identity by presenting the klong yao as representing their own culture. The Chinese and Malay communities also recognised the klong yao as markers of Siamese Thai identity and have integrated klong yao performances into their community functions. The klong yao has played a role in two types of events that connect the Siamese to inside and outside its community. Whether the klong yao is performed in a function that serves religious or other needs, the klong yao represents Thai-ness (or Siamese-ness as like to be called by the Siamese of Perlis). Illustrations and narratives highlight klong yao's functions in ceremonies as examples Siamese attempts to sustain klong yao whereby its status is categorised as a secular performance in both sacred and profane spaces.

Klong yao has been in the Siamese community for an extended period of time and has branched out to many Siamese villages. Klong Yaa accomplishes three roles in the performance process namely: proto-performance, performance and the aftermath. Cultural and personal functions of origin precede the performance. The 
Siamese conduct rehearsals in temples and klong yao's presence gather people because performing the klong yao helps fulfil religious events. During performances, Siamese even try to imitate the action and components of the Thai klong yao. For example, the Siamese only use klong yao for auspicious events or offer it in religious time-space. Furthermore, to understand the whole it is important to discuss the aftermath. The management entity that takes care of the klong yao ensures that klong yao is regularly organised for community events. In terms of cultural conservation, the Siamese created functional performances such as the klong yao competition, making it obvious that the Siamese are producing quality performances.

The findings of this study suggest that the Siamese in Perlis, Malaysia attempt to imitate Thai klong yao as much as possible as representing Thai identity. Songs and lyrics are influenced by central-Thai dialect, costumes originate from traditional central-Thai dresses (royal Thai dress), Thai festival shirts (songkran traditional style), and polo shirts emblazoned with Thai lettering, as well as dancing inherited from the rum vong dance. The image of using klong yao performance tends to strengthen its Thai character. The Siamese refine the image through religion as well. Secondly, the Siamese try to construct another Siamese image in the perception of other ethnic groups. Through the success of constructing Siamese identity for strengthening one's sense of self- the Siamese have also expressed the klong yao performance as an agent of identity. Most Chinese and Malays have called upon klong yao as a positive agent with an image of cooperation, as entertainment and for rituals. Through this positive image, the Siamese desire to be accepted by other ethnic groups has been demonstrated. Klong yao performers have been and continue to be invited to play a role at both Malay and Chinese spaces for decades.

The performance process of klong yao tradition indicates that the Siamese maintained the klong yao in order to sustain their unique Siamese identity. Sustaining Siamese identity is a result of this performance process that was developed not only through visual components such as Thai costuming, but also through musical sounding of Thai-ness. The function of klong yao has developed to be flexible for various occasions and the klong yao tradition has been adapted into the perceptions of other ethnic groups and later gained people's support. The acceptance of klong yao as being on par with Chinese and Malay traditions helps to raise Siamese identity to the national level through events such as the Citrawarna festival and Merdeka Day. Therefore, klong yao performances represent the music and dance of the Siamese across diverse communities in Malaysia.

\section{References}

Amnauysuntikul, P. (2008). Musical study and development of making votive offering ceremony of HOUNG POR TO Wat Satue Tharue Pranakornsri Ayutthaya. (Unpublished master's thesis). Srinakharinwirot University, Bangkok, Thailand.

Aryuwatthana T. (1974). Thai Nai Malaysia (Thai in Malaysia). Bangkok: Bannakit Press.

Buranakiatsakul, P. (2012). The research on 'homrong klong yao' a composition for long drum overture composed by Pra Part Banleng-Rom (Pim Watin) is a case study of 
Kru Songmuang Phanturut group. Unpublished masters thesis. Srinakharinwirot University, Bangkok, Thailand.

Burke, P. J., \& Stets, J. E. (2009). Identity theory. New York, NY: Oxford University Press.

Chuthawichit, Y. \& Yodmalee, B. \& Poklin, S. (2014). The conservation and development of Isan long-drum performances to promote local culture. Asian Culture and Histories Journal, 6(2), 91-195.

Eriksen, T. H. (2010). Ethnicity and nationalism ( $3^{\text {rd }}$ ed.). London: Pluto Press.

Hall, D. G. E. (1981). A history of South-east Asia (4 ${ }^{\text {th }}$ ed.). London, UK: The Macmillan Press Ltd.

Johnson, I. C. (2004). The people with two kings: Space, history and mobility in a Malaysian Thai community. Harvard Universit Doctoral dissertation. Available from ProQuest Dissertation \& Theses database. (UMI No. 3131877)

Matusky, P. (1993). Malaysian shadow play and music continuity of an oral tradition. Kuala Lumpur: Oxford University Press.

Narkseetong, P.\& Putthichot, A. (2012). สถานภาพชุมชนและคนเชื้อไทยในพหุสังคม มาเลเซีย:กรณีศึกษารัฐเกคะห์ ระหว่าง พ.ศ. ๒๕๕๒ - ๒๕๕๐ (Satanapap Chumchon lea Kon ChueThai Nai Pahusangkom Malaysia: KoraneeSuksa Rat Kedah rawang p.s. 2452-2550) Journal of Manussayasart Sangkomsart, Thaksin University, 2.

Numnonda, T. (1978). Pibulsongkram's Thai Nation-Building Programme during the Japanese Military Presence, 1941-1945. Journal of Southeast Asian Studies, 9 (2), 234-247.

Pitupumnak, K. (2018). Paradigm for the development of a Lanna music curriculum in Higher Education in Northern Thailand. Malaysian Journal of music, 7(1), 38-57.

Ross, L. (2011). The hybrid melodic and textual repertoires of Southwest Thailand's Rong Ngeng Tanyong. Proceeding of the $1^{\text {st }}$ Symposium of the ICTM Study Group on Performing Arts of Southeast Asia, Kuala Lumpur: Nusantara Performing Arts Center.

Ryoko, N. (2005). A way of negotiating with the other within the self: Muslim's acknowledgment of Buddhist ancestors in Southern Thailand, 3. Retrieved from http://www.unimuenster.de/Ethnologie/South_Thai/working_paper/Nishii_Nego tiation.pdf

Schechner, R. (2003). Performance theory. London and New York, NY: Routledge.

Winichakul, T. (1994). Siam mapped: A history of the geo-body of a nation. Hawaii: University of Hawaii Press.

Wirunha, C. (2551). บุหงารายา : ประวัติศาสตร์จากคำบอกเล่าของชาวมลายู (Bungaraja: Prawattisart Jak Kambork-law Kong Chao Malayu ). Bangkok: Sakdisopa Press.

Wisuttipat, M. (2016). The theoretical concepts on Thai classical music. Bangkok: Santisiri Press.

\section{Biography}

Chayuti Tassanawongwara is a master student in the Southeast Asian Studies programme at the Department of Southeast Asian Studies, Faculty of Arts and Social Sciences, University of Malaya. He is interested in the music of the Siamese community of northern Malaysia and has completed his thesis entitled "Performing Identity through the klong yao Tradition among the Siamese Community of Perlis, Malaysia. Chayuti obtained his Bachelor of Education in Music Education focusing on traditional Thai music at the Department of Thai music, Faculty of Fine Arts, Srinakharinwirot University, Bangkok Thailand. Currently, his focus of research is in the ethnomusicology of Southeast Asia encompasses identity, 
rituals and performing traditions mainly with Siamese in northern Malaysia and Southern Thai people. He also pays attention at traditional Thai music as his previous background. He was a traditional Thai music teacher, teaching music in countries such as Germany, Philippines, etc.

Hanafi Hussin, Ph.D is an Associate Professor of Cultural Studies at the Department of Southeast Asian Studies at the Faculty of Arts and Social Sciences, University of Malaya. He received B.A and M.A in Southeast Asian Studies with a thesis topic "Philippine Political Theatre during Marcos Regime" and a Ph.D. in Ritual and Performing Arts Studies focusing on ritual and identity of the Kadazan of Sabah, Borneo. He is also researching ritual and performing arts of the maritime communities of Southeast Asia mainly Sama-Bajau and Sama Dilaut of the east coast of Borneo and Southern Philippines. Currently his research and documentation is on tangible and intangible cultural heritage of Indigenous People of Malaysia. Most of his research work published in academic journals relate to regional studies and cultural studies of Southeast Asia. Currently, he serves as Dean, Faculty of Arts and Social Sciences, University of Malaya. 